NBER WORKING PAPER SERIES

\title{
LIQUIDITY REQUIREMENTS, FREE-RIDING, AND THE IMPLICATIONS FOR FINANCIAL STABILITY EVIDENCE FROM THE EARLY 1900S
}

\author{
Mark Carlson \\ Matthew S. Jaremski \\ Working Paper 27912 \\ http://www.nber.org/papers/w27912 \\ NATIONAL BUREAU OF ECONOMIC RESEARCH \\ 1050 Massachusetts Avenue \\ Cambridge, MA 02138 \\ October 2020, Revised March 2022
}

We thank Ellis Tallman and David Wheelock for valuable comments. The views expressed in this paper are solely those of the authors and do not necessarily reflect those of the Board of Governors of the Federal Reserve or its staff. The views expressed herein are those of the authors and do not necessarily reflect the views of the National Bureau of Economic Research.

NBER working papers are circulated for discussion and comment purposes. They have not been peerreviewed or been subject to the review by the NBER Board of Directors that accompanies official NBER publications.

(C) 2020 by Mark Carlson and Matthew S. Jaremski. All rights reserved. Short sections of text, not to exceed two paragraphs, may be quoted without explicit permission provided that full credit, including (C) notice, is given to the source. 
Liquidity Requirements, Free-Riding, and the Implications for Financial Stability Evidence from the early 1900s

Mark Carlson and Matthew S. Jaremski

NBER Working Paper No. 27912

October 2020, Revised March 2022

JEL No. D40,G38,N21,N41

\begin{abstract}
Maintaining sufficient liquidity in the financial system is vital for its stability. However, since returns on liquid assets are typically low, individual financial institutions may seek to hold fewer such assets, especially if they believe they can rely on other institutions for liquidity support. We examine whether state banks in the early 1900s took advantage of relatively high cash balances maintained by national banks, due to reserve requirements, to hold less cash themselves. We find that state banks did hold less cash in places where both state legal requirements were lower and national banks were more prevalent.
\end{abstract}

\author{
Mark Carlson \\ Federal Reserve Board \\ 20th and Constitution Ave., NW \\ Washington, DC 20551 \\ mark.a.carlson@frb.gov \\ Matthew S. Jaremski \\ Utah State University \\ Department of Economics and Finance \\ 3565 Old Main Hill \\ Logan, UT 84322 \\ and NBER \\ matthew.jaremski@usu.edu
}




\section{Introduction}

The interdependence of financial institutions makes financial stability a common resource and creates considerable potential for spillovers (Hanson, Kashyap, and Stein 2011, Cecchetti and Tucker 2015). All institutions benefit when all other institutions are healthy and, conversely, troubles at some institutions could spread to create troubles at other institutions (Allen and Gale 2007). Financial stability is also potentially subject to free-rider problems (Kahn and Wagner 2021). Institutions may not internalize the impacts they have on each other and so may maintain smaller solvency or liquidity buffers to protect themselves against stresses than is optimal from a systemic perspective. This concern has long been recognized and efforts to address it have underpinned requirements ranging from the minimum reserve requirements set by the New York Clearinghouse for member banks in the 1850s (Coe 1873) to the minimum capital requirements for global banks agreed to as part of the Basel capital standards (Basel Committee on Banking Supervision 2011).

Concerns about free-riding were particularly prominent in the United States' National Banking Era (1863-1913) in which there was a dual banking system where some banks were chartered by the national government through the Office of the Comptroller of the Currency (called national banks) and some banks were chartered by state authorities (called state banks). White (1983) documents how state and national banking authorities lowered capital requirements to entice banks to adopt a state versus national charter. (Indeed, as discussed below, previous work finds that capital requirements were a primary determinant of charter choice.) As equity capital is important in promoting bank health and providing a buffer such that loan losses do not cause losses to bank liability holders - including other banks - allowing entry by banks with less capital might have reduced the stability of the banking system (Wheelock and Wilson 1995). 
In this paper, we examine another possible instance in which regulatory differences might have led to free riding, again with potential implications for financial stability. Reserve requirements were a prominent regulatory tool in the National Banking Era. These requirements mandated that banks hold a certain amount of cash and other liquid assets against certain liabilities in order to ensure that they had sufficient resources to meet deposit withdrawals under most circumstances (Comptroller 1863). National banks faced a relatively strict set of requirements regarding the cash that they had to hold in proportion to their deposit base. ${ }^{1}$ State banks also frequently faced cash reserve requirements, though the severity of these rules varied. In some places, they were at least as tight as those for national banks while in other places they were notably easier. The question we address in this paper is whether state banks took advantage of lower cash requirements relative to those imposed on national banks to hold less cash.

Banks need a sufficient supply of liquid assets to operate smoothly and meet withdrawals; therefore, banks would hold some cash even where cash reserve requirements were minimal or non-existent. However, state banks subject to lower requirements might have held less cash if they were confident that other nearby banks (i.e. national banks) held a fair amount of cash due to higher cash requirements which the state banks might be able to access if their own supply ran low. To examine whether state banks were free riding in this way, we test whether cash holdings were lower for state banks in cities located in states where the cash reserve requirements were lower and in which national banks held substantial cash reserves.

We conduct our tests regarding cash holdings using individual bank-level data from 1905 through 1909 for 25 states. The time period is chosen for several reasons. First, detailed information on reserve requirements for all states was included in the report of the National

\footnotetext{
${ }^{1}$ At the start of the National Banking Era, national banks also had to hold a reserve against their note circulation. By the time period analyzed in this paper, that part of the requirement had been dropped.
} 
Monetary Commission in 1910. Second, many states had begun reporting balance sheet information by this time allowing us to control for other bank-level factors that might impact cash holdings. Third, the period includes the Panic of 1907, one of the most severe panics of the National Banking Era, which allows us to examine free-riding behavior around the time of a financial shock. We stop the analysis in 1909 , as there was a change in the monetary regime at this time (caused first by the passage of the Aldrich-Vreeland Act in 1908 and then the passage of the Federal Reserve Act in 1913).

Consistent with contemporary complaints by national banks, we find evidence of free riding by state banks. State banks facing lower cash reserve requirements and in close proximity to more national banks tended to hold less cash. Our estimation results indicate that a state bank in a state with easier requirements that was located in a city with an average number of national banks had about a ten percent lower cash-to-asset ratio than a state bank in a similar city in a state with reserve requirements as tight as or tighter than those imposed on national banks.

We also consider whether the reduction in cash holdings was consequential during the Panic of 1907. In particular, we test whether cash holdings are associated with the continued operation of banks in 1908 that had been operating in 1906 after controlling for other balance sheet measures. Similar to previous work on the value of holding liquid assets during periods of stress, we find that cash holdings are associated with the likelihood of continued operation in our sample, which suggests that the reduction in cash holdings by state banks impacted their likelihood of survival. This finding may also provide a rationale for the reduction in free riding behavior after 1907 as banks that survived might have been prompted to change their behavior.

The paper proceeds as follows. Section 2 discusses the regulatory environment in the early 1900s, focusing in particular on reserve requirements. Section 3 discusses the data. Section 
4 presents our analysis of the cash holdings of state banks and whether their cash holdings were affected by differences in requirements and the presence of national banks. In Section 5, we discuss the impact of cash holdings on whether the banks continued to operate following the Panic of 1907. Section 6 concludes.

\section{The Regulatory Environment}

The banking environment in the National Banking Era can most charitably be described as disjointed. One group of banks were the national banks chartered by a federal agency and subject to a uniform set of standards across all states that are described in the Annual Reports of the Comptroller of the Currency. Existing side-by-side with the national banks were statechartered banks which were regulated by their respective states and subject to rules that varied across the country. Unlike national banks, getting information on the state bank rules is not always straightforward. We use the set of rules compiled by Welldon for the National Monetary Commission (1910).

As noted earlier, some regulations between state and national banks differed notably. One such regulation, which has been discussed relatively extensively in the previous literature, is capital requirements. For instance, as of 1909, the minimum capital requirement for establishing a national bank in towns where the population did not exceed 3,000 was $\$ 25,000$; while for some states a bank could be started in a similarly sized town with a minimum capital of only $\$ 10,000$.

While minimum capital requirements also varied across state and national banks, they were quantity requirements rather than ratio requirements and thus served mostly as an entry barrier rather than a barrier to risk-taking. To understand how differences in regulations may have affected risk taking behavior, the regulation that we focus on in this paper is reserve 
requirements. The National Banking Acts of 1863 and 1864 established reserve requirements for national banks. In the period we look at, national banks in central reserve cities (i.e., New York City, Chicago, and St Louis) were required to hold 25 percent reserve in vault cash. National banks in reserve cities (e.g., large regional centers) had to hold 25 percent reserve but only half that amount needed to be held as vault cash; the rest could be on deposit in a central reserve city national bank. The remaining "country" national banks only had to maintain a 15 percent reserve of which two-fifths needed to be held on site, while the remainder could be held on deposit at a national bank in a central reserve city or reserve city. In this paper, we focus on the portion of the reserve that needed to consist of cash.

State banks were usually, though not always, subject to a cash reserve requirement. (State banks might also have had total reserve requirements that allowed for some portion to consist of non-cash assets. As with the national banks, we focus on the portion of the requirement that needed to consist of cash.) Given our interest in whether state banks were free-riding on the cash reserves of national banks, it is helpful to classify state requirements relative to the national requirements to determine whether the state banks could have held less cash than national banks if they had desired. The state regulations and whether we classify those rules as easier, tighter, or the same as for national banks appear in Table 1; states in italics are not included in our sample, but are included for comparison purposes. For about half of the states in our sample- 12 of the 25 states - we find that the reserve requirements imposed on the state banks were unconditionally more lenient than those imposed on national banks. The reserve requirements were the same in many states and were unconditionally tighter in a handful states. In several states, the differences between state laws and national laws depended either on the size of the city in which the bank was located or on the distribution of deposits held by banks. As an 
example of the former, the reserve requirement in Kansas was 5 percent of deposits held in cash for locations under 5,000 people yet 6.25 percent of deposits held in cash for more populated locations. An example of latter, the reserve requirement in Texas was 25 percent of demand deposits with at least two-fifths held as cash (i.e. 10 percent of demand deposits) yet there was no reserve requirement on time deposits. In the former case, we account for population in the analysis while in the latter case, we treat them as having the same reserve requirements as national banks. (The results are similar if we instead omit these states.)

Reserve requirements were only one of the regulations that differed between state and national banks. As noted above, the minimum capital required to open a bank differed between state and national banks. As of 1909, the minimum capital requirement for establishing a national bank was $\$ 25,000$ in towns where the population did not exceed 3,000; in some places, a state bank could be started in a similarly sized town with a minimum capital of only $\$ 10,000$. Further, national banks were restricted from originating loans backed by real estate, while state banks generally were not; that difference could be particularly important in rural communities. In addition, some states allowed their state banks to establish limited branching networks and some states had deposit insurance systems—-sometimes voluntary and sometimes compulsory.

Importantly for our analysis, many of these other differences in the regulatory environment appear to have been the primary drivers of the choice between state charters and national charters. White (1983) highlights that low minimum capital requirements, deposit insurance, and branch banking led to significantly more entering banks to adopt a state charter rather than a national charter. By contrast, reserve requirements appear to have ambiguous effects; White finds a positive correlation between state bank charters and the amount of reserves on demand deposits kept as vault cash but a negative correlation with the total amount of 
reserves on demand deposits. Because most rural areas could not support a large bank, authors studying the period (e.g., Barnett 1911, Mitchener and Wheelock 2013, Fulford 2015) typically highlight minimum capital requirements, branching restrictions, and deposit insurance as determinants of bank entry and charter choice rather than reserve requirements. For instance, Barnett (1911, p. 111) writes: "Even since the revival of state bank regulation, which began in 1887, the requirement of a reserve has not been regarded in many of the States as an important part of the state banking law." Moreover, the National Banking period was one of rising state reserve requirements rather than declining ones. As such, while the distribution of state-tonational banks in a state might partially relate to the size of the state's reserve requirement, we do not believe it to be a large influence. Regardless, in the empirical analysis that follows, we directly control for the general effect of national banks as well as the number of banks in a location.

\section{Data}

Given that the information on state laws was published in 1910 (but collected in the previous years), we use bank data that come from 1905 to 1909 . While the Comptroller of the Currency's Annual Report contains the annual balance sheet of every national bank in operation each year, some states did not report balance sheet information on their banks until after 1910, and those that did report data often only did so every other year (Mitchener and Jaremski 2015). It is not until the year 1905 that enough states with enough different reserve requirements 
provided data sufficient to conduct our analysis. We digitized the data of the 25 states that published data starting in 1905 or earlier, which are listed in Table $1 .{ }^{2}$

We stop the analysis in 1909, shortly after the passage of the Aldrich-Vreeland Act in 1908. This Act allowed the formation of local currency associations that would issue liquidity to member banks during panics and appears to have changed the liquidity dynamics of the financial system. Bernstein, Hughson, and Weidenmier (2010) find that interest rate and equity market volatility declined following this Act; they attribute this decline in volatility to a decline in liquidity risk in conjunction with the new monetary regime. Such a reduction in liquidity risk would likely have changed the behavior of banks and in particular their cash holdings.

To create a consistent measure of cash holdings across the various states, we aggregate unique balance sheet items listed in a few state reports into more common items. For example, cash in vault, gold coin, silver coin, minor coins, checks, and reserves are merged into a single cash variable measure. We also avoid extreme outliers and potential data errors by dropping banks that had ratios of cash to assets below 1 percent or, at some point in the sample period, had ratios above 30 percent. The results are generally robust to modest adjustments in this cutoff.

\section{Analysis of cash holdings at state banks}

There was a profitability incentive to minimize cash holdings. The interest rates that banks earned on their loans were reported to have averaged around 6.5 percent in the $1890 \mathrm{~s}$ (Breckenridge 1898, James 1974). The return on quite safe and liquid assets—balances at correspondent banks in New York City—typically earned rates of around 2 percent. Cash

\footnotetext{
${ }^{2}$ To include the largest number of locations and banks, we do not restrict ourselves to a balanced panel. Because some states did not report balance sheet information in one of the years, a balanced panel would restrict the sample to only 16 states. The results for the balanced panel display the same pattern but with reduced statistical precision.
} 
holdings, by contrast, earned no interest. Thus, bank shareholders had a financial incentive to, at the margin, make more loans and economize on cash holdings.

In addition to meeting cash reserve requirements, banks had to maintain sufficient cash to meet deposit withdrawals when they occurred. However, state banks may have believed that they could have obtained cash when needed from nearby banks. James, Weiman, and McAndrews (2013) note that large cities had interbank markets for cash and it is quite possible that arrangements for banks to obtain cash from each other existed in smaller towns as well. As national banks tended to be required to have more cash on hand, we expect that state banks would have been better positioned to take advantage of these markets to reduce cash holdings.

In addition, state banks may have believed that even in a crisis, they would have been able to obtain cash from national banks as the national banks would have felt it was in their own interest to keep the state banks afloat because the closure of a state bank might trigger a more widespread run. The contemporary financial press reported that such a dynamic was in place prior to the Panic of 1893 (Banker's Magazine, April 1894, p. 723) stating: "It is believed in times of stringency the National institutions must come to the rescue for the other [state banks] in order to protect themselves. This feeling is shared quite generally by bankers." Reinforcing this idea were statements by the Comptroller of the Currency, the chief regulator of the national banks, that reserve requirements for national banks would be relaxed in times of crisis which would have made the cash holdings of national banks even more accessible to state banks (Carlson 2015).

Based on these incentives, our hypothesis is that state banks will hold lower cash balances where (1) they allowed to by law and (2) where cash balances at nearby national banks were relatively ample. Both conditions matter for this hypothesis. The regulatory requirement is 
clearly important. In states where the reserve requirements were relatively low, banks may have held less cash, while in states where the reserve requirements were the same as or higher for the national banks, we would not expect much difference. We account for state bank requirements using a dummy variable for whether a state had relatively looser requirements. The second condition concerns the cash holdings of nearby national banks. For the cash balances of the national banks to have been sufficient to affect the behavior of the state banks, there would have to be nearby national banks of meaningful size and they would have to have sizable cash holdings. ${ }^{3}$ We measure the importance of the local national banks using the share of total bank assets in the city that consisted of the assets of national banks. Our measure of the cash holdings of national banks is the total cash of all national banks in the area divided by the total assets of those national banks (one could interpret this measure as the average cash-to-asset ratio weighted by bank size). Our expectation is that the impact of the cash holdings of national banks, in combination with their importance, will matter in locations where state banks were able to hold lower levels of reserves (but not in places where state banks were required to hold as many reserves as national banks).

Various other bank characteristics might influence cash holdings. Larger banks may benefit from having more depositors and, based on the law-of-large-numbers, have smaller net day-to-day changes in deposits as deposit withdrawals would be more likely to be offset by inflows. Consequently, larger banks might need to hold less cash. The capital position of the bank could also be important with better capitalized banks needing to hold less cash (Calomiris

\footnotetext{
${ }^{3}$ If the national banks were much smaller than the state banks, then we would not expect that the state banks would hold less cash. (If there were four banks in a town - three large state banks and one small national bank then we would not expect that those state banks would be much affected by the cash holdings of the national bank.)
} 
and Wilson 2004). ${ }^{4}$ Our measures of the capital position of the bank include both the ratio of net worth (capital paid in, surplus, and undivided profits) to assets and the ratio of surplus, and undivided profits to net worth. Surplus and undivided profits tended to reflect retained earnings and thus may reflect the quality of the bank's capital position.

Other location factors, besides the cash position of nearby banks, might also influence the cash holdings of the bank. For instance, areas with larger or more urban populations might have more transactions and thus higher liquidity needs. Areas with more manufacturing firms may have greater need for long-distance transactions so banks might hold a larger portion of their liquid assets as balances at other banks, as was found by Calomiris and Carlson (2017), rather than as cash. We also control for whether the city is a reserve city, whether the city had an active clearinghouse, and the log of the number of banks nearby.

Putting these parts together and including the relevant interaction terms, the specification we use in our regressions is:

$$
\begin{aligned}
& \text { Reserves }_{i, t}=\alpha+\beta_{1} \text { NBShare }_{i, t}+\beta_{2} \text { NBReserve }_{i, t}+\beta_{3} \text { RREasier }_{i, t}+ \\
& \beta_{4} \text { NBShare }_{i, t} * \text { NBReserve }_{i, t}+\beta_{5} \text { NBShare }_{i, t} * \text { RREasier }_{i, t}+ \\
& \beta_{6} \text { NBReserve }_{i, t} * \text { RREasier }_{i, t}+\beta_{7} \text { NBShare }_{i, t} * \text { NBReserve }_{i, t} * \text { RREasier }_{i, t}+ \\
& \beta_{8} \text { BalSheet }_{i, t}+\beta_{9} X_{i}+t_{t}+e_{i, t}
\end{aligned}
$$

where Reserves $_{i}$ is the ratio of cash to assets of state bank $i, N B S h a r e_{i, t}$ is the ratio of national bank assets to total state and national bank assets in a location, NBReserve $e_{i, t}$ is the ratio of total national bank cash to assets in a location, $R R E a$ sier $_{i}$ is a dummy variable that takes a value of "1" if the state bank reserve requirement was relatively easier than the national bank requirement.

\footnotetext{
${ }^{4}$ Similarly, Calomiris, Heider, and Hoerova (2015) argue that higher holding of cash may have been a way that banks demonstrated their safety. If the nearby national banks were demonstrating their safety by holding more cash, then that would likely increase the pressure on the state banks to hold more cash to demonstrate their own safety. Thus, the effect should be in the opposite direction of what we predict.
} 
BalSheet $_{i, t}$ is a vector of bank balance sheet controls including the logarithm of assets, the ratio of capital to assets, the ratio of surplus to capital and surplus, and the ratio of due to banks to deposits. $X_{i}$ is a vector of city-level controls, including whether the city is a reserve city and the logarithm of the number of banks in the city, and county-level Census controls from Haines (2004) including the logarithm of population, the share of the population defined living in a location of more than 2,500 people (i.e., an urban location), the share of population that was nonwhite, the logarithm of manufacturing firms. $t_{t}$ is a vector of time fixed effects. $e_{i, t}$ is the robust error term. (We estimate equation (1) both with and without the city and county controls.) Summary statistics for the variables in the year 1906 are in Table 2. Those for other years are similar. ${ }^{5}$

In order to be able to obtain cash from nearby banks, it seems reasonable that there must a sufficient number of banks nearby from which a bank might expect to be able to obtain that cash. It is uncertain how large the interbank market for cash balances, which we noted above as a mechanism that would permit free-riding, would be if there were only a couple banks in the town. Thus, in our analysis, we limit the sample to towns in which there are at least four banks. In addition, it seems possible that very heavily banked cities could be quite different. For instance, banks in central reserve cities and important regional reserve cities, may have been held to different standards if they wanted to compete for interbank deposits. Moreover, clearinghouses in these cities may have set higher rules; for instance, the New York City Clearinghouse required all members, both state and national banks, to meet the legal reserve requirements of the national

\footnotetext{
${ }^{5}$ It is possible that, rather than affecting the absolute level of cash held by banks, the free-riding behavior might have led banks to maintain a smaller buffer of cash beyond their reserve requirement. However, many states did not published sufficiently detailed deposit data to calculate this ratio correctly, especially as a number of reserve requirements differed between demand and time deposits. Estimating equation (1) using this more limited sample of banks and looking at whether the buffer of cash held in excess of the requirement was affected by cash held at national banks are generally consistent with the results reported below.
} 
banks. To account for these potential differences, we exclude cities with 20 or more banks. ${ }^{6} \mathrm{We}$ discuss sensitivity of our results to these cutoffs below.

We pool all the years between 1905 and 1909 to test whether state banks displayed behavior consistent with free riding. Specifically, we are interested in testing whether $\beta_{7}$ in equation (1) is negative, which would signal that state banks in states with easier reserve requirements and in locations with sufficient national bank cash reserves chose to hold significant less cash than state banks that did not meet those conditions. ${ }^{7}$ As shown in Table 3, we do indeed find a strong negative coefficient on the interaction term which is consistent with our hypothesis. This is true regardless of whether we conduct the estimation without the city and county controls (column 1) or with those controls (column 2 ). ${ }^{8}$ We also find that state banks tended to hold more cash in places where national banks were a larger share of the local bank population and where national banks tended to hold more cash. ${ }^{9}$ To illustrate the economic effects of the laws versus the cash holdings of nearby banks and what these various interaction effects imply, we compare banks using the effects based on the coefficients and data means from the pooled sample. The coefficients from the specification reported in column 2 indicate that a bank in a state with reserve requirements as tight as those of the national banks and with all other covariates set at the mean would be predicted to have had a cash-to-asset ratio of 6.4 percent. For comparison, a bank in a town located in a state that allowed lower reserve requirements but was the same in all other ways, would be predicted to have a cash ratio of 5.8 percent, a noticeably lower ratio.

\footnotetext{
${ }^{6}$ By cutting off locations with 20 or more banks, we exclude 14 cities in 1906: Chicago, Cincinnati, Cleveland, Columbus, Kansas City (MO), Los Angeles, Minneapolis, New Orleans, New York City, Philadelphia, Pittsburgh, San Francisco, St Louis, and Toledo. The list of cities grows slightly over time but is very similar.

${ }^{7}$ While in some cases triple interaction terms can result in the coefficient being estimated from a small number of observations, in our case over 40 percent of the observations have a non-zero value.

${ }^{8}$ Further discussion of the effects of including or excluding various location controls is founds in Section 1 of the online appendix.
} 
As noted above, we restricted our sample to towns with more than three banks and less than twenty. Adding towns with three banks or two banks does not change the results, both the economic and statistical significance are the same as with our preferred sample. If we estimate equation (1) just using towns with two or three banks, we find that the effect is less precisely estimated though of fairly similar economic significance. As would be expected due to differential reserve requirements, adding the few towns with twenty or more banks reduces the economic and statistical significance of our finding that having national banks hold more cash results in state banks holding less cash. ${ }^{10}$

The other variables generally have the expected effects. Larger banks tended to hold less cash. Banks in which a greater share of their liabilities consisted of the deposits of other bankswhich tend to be more volatile (Carlson 2015) — tended to hold more cash on hand. Banks in cities with a higher population tended to have more cash on hand. The presence of a clearinghouse also tended to increase the amount of cash held by banks. Interestingly, all else equal, we find that the presence of more banks nearby tended to reduce the amount of cash held by banks.

Next we examine if there is any differential behavior over time. The Panic of 1907 was a severe financial crisis that resulted in a widespread and scramble for liquidity and the suspension of convertibility of deposits to cash by clearinghouse associations across the country and a collapse of the payment system (Sprague 1910). If state banks were free-riding before the Panic, they might have been in even more trouble during 1907. It is even possible that they changed their ways after the Panic. We, therefore re-estimate equation (1) including interaction of our triple interaction term with the year fixed effects. These results are reported in Table 4 . The

\footnotetext{
${ }^{9}$ The latter result suggests that there may have been an incentive to not look too much less liquid than nearby banks.
} 
coefficients on the interaction term of interest (the fraction of city assets at national banks * cash holdings of national banks * easier state reserve requirement) with the year dummies are positive and statistically significant for 1908 and 1909. This suggests that there may have been a reduced tendency on the part of banks to rely on others for cash following the panic than before.

\section{Cash holdings and bank survival after the panic}

The results above indicate that some state banks reduced their cash holdings in the presence of national banks, which were required to hold more cash, but the tendency of free riding behavior was somewhat mitigated coming out of the Panic of 1907. The panic was particularly associated with the lack of liquidity. Starting due to a failed corner on United Copper Company stock in New York City, the panic spilled over to the rest of the country when New York City banks suspended payments and left banks without access to their interbank deposits. ${ }^{11}$ As a result, there were widespread cash shortages which resulted in the issuance of scrip and suspension of banking activities in a large number of cities (Andrew 1908, Sprague 1910, Wicker 2000, Gorton and Tallman 2018). Overall, these reports point to a lack of cash availability being a problem at a systemic level.

A variety of previous work has found that greater holdings of cash have been valuable for supporting banks during periods when the banking sector has been under considerable stress.

This literature includes, for example, White (1984), Wheelock and Wilson (1995, 2000), Calomiris and Mason (2003), and Jaremski and Wheelock (2020). In this section, we look for evidence that greater holdings of cash were beneficial for the banks in our sample and,

\footnotetext{
${ }^{10}$ It is not until we include the nine towns with 28 or more banks that the coefficient becomes statistically insignificant. Section 2 of the online appendix discusses the robustness of our results to alternative cutoffs.

${ }^{11}$ The Trust Companies of New York City were provided extraordinary support, coordinated by J.P. Morgan. We exclude these Trust Companies from our sample.
} 
specifically, whether of the cash holdings of banks prior to the panic are associated with their continued operation following the panic. The analysis provides some sense of whether there were consequences at the individual bank level from the lower cash holdings, and may help us understand whether the change in free riding behavior could have been driven by banks realizing they were not protected during the panic.

The outcome variable we construct is whether a bank that provided data in 1906 also provided data in 1908. Banks that did not do so are assumed to have ceased operations. (An important caveat is that the panic of 1907 featured the temporary suspensions of all banks in some towns, possibly due to inadequate cash holdings in the community, but that these suspensions are not captured by our measure. Nevertheless, it is helpful to see whether the findings regarding the value of cash found by others are present in our sample.) Similar to those estimated by others, we regress that outcome variable on our cash-to-asset ratio, other balance sheet ratios, and county-level controls. There are some tradeoffs in conducting this estimation with larger samples versus comparability with the set of bank analyzed above so we use a few different sets of banks: all state banks, state banks located in a town with at least one bank of any type, state banks located in towns with at least one national bank, and the set of state banks used elsewhere in the paper - those in cities with between four and nineteen banks. The model is:

$$
\text { Closure }_{i, 1906-08}=a+\beta_{1} \text { Reserves }_{i, 1906}+\beta_{2} \text { BalSheet }_{i, 1906}+\beta_{3} X_{i, 1906}+e_{i}
$$

where Closure $_{i, 1906-08}$ is an indicator variable for whether a bank stopped reporting between 1906 and 1908 and the rest of the variables retain their definitions.

The results of equation (2) are in Table 5. In general, we find that banks that held more cash were less likely to cease operations by 1908 . The effect is statistically stronger when we use the larger samples so long as we exclude single-bank towns but the negative association 
between holding more cash and a lower likelihood of exit is consistent throughout. Moreover, we find a stronger connection between cash and closure in those places with at least one national bank, suggesting free riding might have contributed to closures during the panic. When we compare the size of the reduction in cash holdings noted above however (for a bank in a state with tight restrictions having average cash holding of 6.4 percent while similar bank in a state with easier cash holdings having cash holdings of 5.8 percent), we find that the estimated impact of this reduction in cash would result in somewhere around a 0.15 percentage point increase in the likelihood of closure. Hence for the average bank in a state with easier reserve requirements, the increased likelihood of a closure was modest, though perhaps not inconsequential. For banks a bit further from the mean where cash holdings were reduced more, the increase in failure risk would have been quite meaningful.

\section{Conclusion}

Our paper examines whether some financial institutions were free-riding on the liquidity of the other financial institutions. Holding cash can be costly in terms of opportunities foregone so banks may have preferred to minimize cash on their balance sheet. We find that for state banks that were subject to lower cash reserve requirements and that were located near national banks where cash requirements were higher, tended to hold less cash. It is possible that this reliance by state banks on cash holdings of national banks increased the severity of liquidity pressure during the Panic of 1907. Such a dynamic has been well noted in other circumstances. Sprague (1908) reports that the dependence by trust companies on the liquidity of New York Clearinghouse members increased the stresses on the clearinghouse member banks during the Panic of 1907. Similarly, Mitchener and Richardson (2019) show that the reliance of smaller 
banks on other banks for liquidity added to the strains on the banking sector in the Great Depression.

The findings in this paper offer some lessons for financial stability today. In the wake of the recent financial crisis, there has been renewed interest and emphasis on liquidity requirements. For instance, large and internationally active commercial banks are now subject to a liquidity coverage ratio (LCR) that stipulates that these banks must hold particular quantities of high-quality liquid assets in proportion to particular liabilities (See Board of Governors of the Federal Reserve, 2014). Prime money market funds are also subject to new liquidity rules (Securities and Exchange Commission 2016). However our findings highlight a concern about having some parts of the financial system covered by liquidity requirements while other parts of the system are not covered. As shown in Section 4, institutions not covered by rules may believe that increased holdings of liquidity on the part of covered institutions may allow them to operate with lower liquidity holdings because they can depend on the covered institutions to supply liquidity when needed. Indeed, Yankov (2020) finds some evidence that nonbank financial institutions-such as insurance companies, finance companies, asset managers, and others decreased their liquid assets and increased their reliance on bank credit lines to manage their liquidity risks following the adoption of the LCR. This dynamic could increase the pressure on the covered institutions during a stress event and points to the importance of understanding the liquidity position of the financial system as a whole. 


\section{References}

Allen, Franklin, and Douglas Gale. (2007) Understanding Financial Crises. Oxford: Oxford University Press.

Andrew, Abram Piatt. (1908) "Substitutes for Cash in the Panic of 1907." Quarterly Journal of Economics, 22, 499-519.

Bankers Magazine. (1894) New York: Homans Publishing (April).

Barnett, George. (1911) State Banks and Trust Companies Since the Passage of the NationalBank Act. Washington, DC: US Government Printing Office.

Basel Committee on Banking Supervision. (2011) Basel III: A Global Regulatory Framework for More Resilient Banks and Banking Systems - Revised Version June 2011. https://www.bis.org/publ/bcbs189.htm.

Bernstein, Asaf, Eric Hughson, and Marc D. Weidenmier. (2010) "Identifying the Effects of a Lender of Last Resort on Financial Markets: Lessons from the Founding of the Fed." Journal of Financial Economics, 98, 40-53.

Board of Governors of the Federal Reserve System. (2014) "Federal Banking Regulators Finalize Liquidity Coverage Ratio," Joint Press Release, https://www.federalreserve.gov/newsevents/pressreleases/bcreg20140903a.htm

Breckenridge, R. M. (1898) "Discount Rates in the United States," Political Science Quarterly, $13,126$.

Calomiris, Charles W. and Mark Carlson. (2017) "Interbank networks in the National Banking Era: Their purpose and Their Role in the Panic of 1893," Journal of Financial Economics, $125,434-53$.

Calomiris, Charles W., Florian Heider, and Maria Hoerova. (2015) "A Theory of Bank Liquidity Requirements.” Columbia Business School Research Paper No. 14-39.

Calomiris, Charles W. and Joseph Mason. (2003) "Fundamentals, Panics, and Bank Distress During the Depression." American Economic Review, 93(5), 1615-47

Calomiris, Charles W. and Berry Wilson. (2004) "Bank Capital and Portfolio Management: The 1930s "Capital Crunch" and the Scramble to Shed Risk." Journal of Business 77, 421-56.

Carlson, Mark. (2015) "Lessons from the Historical Use of Reserve Requirements in the United States to Promote Bank Liquidity.” International Journal of Central Banking 11, 191-224.

Cecchetti, Stephen, and Paul Tucker. (2015) "Is there Macroprudential Policy Without International Cooperation?” CEPR Discussion Paper No. 11042.

Coe, George. (1873) Report to the New York Clearing House Association. New York: W. H. Arthur \& Company.

Comptroller of the Currency. (1863) Annual Report of the Comptroller of the Currency. Washington DC: US Government Printing Office.

Fulford, Scott. (2015) "How Important Are Banks for Development? National Banks in the United States, 1870-1900.” Review of Economics and Statistics 97, 921-38. 
Gorton, Gary, and Ellis Tallman. (2018) Fighting Financial Crises: Learning from the Past. Chicago: University of Chicago Press.

Haines, Michael. (2004) Historical, Demographic, Economic, and Social Data: The United States, 1790-2000. ICPSR Study 2896. Ann Arbor, MI: ICPSR.

Hanson, Samuel, Anil Kashyap, and Jeremy Stein. (2011) “A Macroprudential Approach to Financial Regulation,” The Journal of Economic Perspectives, 25(1), 3-28.

James, John. (1974) Money and Capital Markets in Postbellum America, Princeton: Princeton University Press.

James, John, David Weiman, and James McAndrews. (2013) "Wall Street and Main Street: The Macroeconomic Consequences of New York Bank Suspensions 1866-1914." Cliometrica 7, 99-130.

Jaremski, Matthew, and David Wheelock. (2020) "Banking on the Boom, Tripped by the Bust: Banks and the World War I Agricultural Price Shock." Journal of Money, Credit, and Banking, 52, 1719-54.

Kahn, Charles and Wolf Wagner (2021). "Sources of Liquidity and Liquidity Shortages," Journal of Financial Intermediation, 46.

Mitchener, Kris and Matthew Jaremski. (2015) "The Evolution of Bank Supervisory Institutions: Evidence from American States," Journal of Economic History, 75, 819-59.

Mitchener, Kris, and Gary Richardson. (2019) "Network Contagion and Interbank Amplification during the Great Depression," Journal of Political Economy, 127, 465-507.

Mitchener, Kris, and David Wheelock. (2013) "Does the structure of banking markets affect economic growth? Evidence from US state banking markets," Explorations in Economic History 50, 161-78.

Securities and Exchange Commission. (2016) "Investment Company Liquidity Risk Management Programs," Final Rule, https://www.sec.gov/rules/final/2016/33-10233.pdf

Sprague, Oliver M. W. (1908) “The American Crisis of 1907," The Economic Journal, 18, 35372.

Sprague, Oliver M. W. (1910) History of Crises Under the National Banking System, Washington, DC: United States Government Printing Office.

Welldon, Samuel. (1910) Digest of State Banking Statutes, Report of the National Monetary Commission, Washington, DC: US Government Printing Office.

Wheelock, David and Paul Wilson. (1995) "Exploring Bank Failures: Deposit Insurance, Regulation, and Efficiency," The Review of Economics and Statistics, 77(4), 689-700.

Wheelock, David and Paul Wilson. (2000) "Why Do Banks Disappear? The Determinants of U.S. Bank Failures and Acquisitions," Review of Economics and Statistics, 82, 127-38.

White, Eugene. (1983) The Regulation and Reform of the American Banking System, 1900-1929. Princeton: Princeton University Press.

White, Eugene. (1984) “A Reinterpretation of the Banking Crisis of 1930." Journal of Economic History, 44, 119-38. 
Wicker, Elmus. (2000) Banking Panics of the Gilded Age. Cambridge: Cambridge University Press.

Yankov, Vladimir. (2020) "The Liquidity Coverage Ratio and Corporate Liquidity Management." FEDS Notes. Washington: Board of Governors of the Federal Reserve System, February 26, 2020, https://doi.org/10.17016/2380-7172.2509. 
Table 1

Reserve requirements by state

\begin{tabular}{|c|c|c|c|c|}
\hline State & Reserve requirement that must be in cash & $\begin{array}{c}\text { Comparison } \\
\text { to National } \\
\text { Banks }\end{array}$ & $\begin{array}{c}\text { Number } \\
\text { of } \\
\text { locations } \\
\text { in } 1906 \\
\end{array}$ & 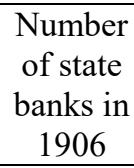 \\
\hline National Banks & 6 percent of deposits (demand, time, and net interbank) & & & \\
\hline Alabama & 6 percent of demand deposits & Easier & 6 & 23 \\
\hline Arizona & 6 percent of all deposits & Same & & \\
\hline Arkansas & Little legislation regulating banks & Easier & & \\
\hline California & 6 percent of deposits & Same & 23 & 70 \\
\hline Colorado & None reported & Easier & & \\
\hline Connecticut & 4 percent of deposits & Easier & & \\
\hline Delaware & $\begin{array}{l}3^{1} / 3 \text { percent of deposits (if pop. }<50,000 \text { ) } \\
5 \text { percent of deposits (if pop }>50,000 \text { ) }\end{array}$ & Easier & & \\
\hline Florida & 8 percent of deposits & Tighter & 1 & 2 \\
\hline Georgia & $\begin{array}{l}\text { None (Entire reserve may consist of deposits in other } \\
\text { banks) }\end{array}$ & Easier & 10 & 33 \\
\hline Idaho & 7.5 percent of demand deposits & Easier & 4 & 11 \\
\hline Illinois* & 6 percent of deposits & Same & 14 & 25 \\
\hline Indiana & No requirement & Easier & 18 & 46 \\
\hline Iowa & 2.5 percent of deposits & Easier & 24 & 77 \\
\hline Kansas & $\begin{array}{l}5 \text { percent of deposits (if pop. }<5,000 \text { ) } \\
6.25 \text { percent of deposits (if pop }>5,000 \text { ) }\end{array}$ & $\begin{array}{l}\text { Easier } \\
\text { Same }\end{array}$ & 11 & 35 \\
\hline Kentucky & $\begin{array}{l}5 \text { percent of deposits (if pop. }<50,000 \text { ) } \\
8^{1} / 3 \text { percent of deposits (if pop }>50,000 \text { ) }\end{array}$ & $\begin{array}{l}\text { Easier } \\
\text { Tighter }\end{array}$ & & \\
\hline Louisiana & $\begin{array}{l}8 \text { percent of demand deposits (plus additional } \\
\text { requirements) }\end{array}$ & Unclear & 2 & 4 \\
\hline Maine & 5 percent of deposits & Easier & & \\
\hline Maryland & None reported & Easier & & \\
\hline Massachusetts & $\begin{array}{l}\text { Possible for entire reserve to consist of deposits in } \\
\text { other banks }\end{array}$ & Easier & & \\
\hline Michigan & 7.5 percent of deposits & Tighter & 9 & 38 \\
\hline Minnesota & 10 percent of demand deposits & Unclear & 3 & 9 \\
\hline Missouri & $\begin{array}{l}\text { Reserve requirement, but banks determine the share to } \\
\text { be kept as cash }\end{array}$ & Easier & 13 & 46 \\
\hline Montana & $\begin{array}{l}\text { Reserve requirement, but banks determine the share to } \\
\text { be kept as cash }\end{array}$ & Easier & 4 & 6 \\
\hline Nebraska & $\begin{array}{l}6 \text { percent of deposits (if pop. }<25,000 \text { ) } \\
8 \text { percent of deposits (if pop }>25,000 \text { ) }\end{array}$ & $\begin{array}{l}\text { Same } \\
\text { Tighter }\end{array}$ & 7 & 12 \\
\hline Nevada & 5 percent of deposits & Easier & & \\
\hline New Hampshire & None reported & Easier & & \\
\hline New Jersey & 6 percent of demand deposits & Easier & 2 & 3 \\
\hline New Mexico & None reported & Easier & & \\
\hline
\end{tabular}




\begin{tabular}{|c|c|c|c|c|}
\hline New York & 6 percent of deposits & Same & 15 & 40 \\
\hline North Carolina & 6 percent of deposits & Same & - & - \\
\hline North Dakota & 8 percent of deposits & Tighter & 5 & 9 \\
\hline Ohio & 6 percent of demand and 4 percent of time deposits & Easier & 23 & 52 \\
\hline Oklahoma & $\begin{array}{l}6.7 \text { percent of deposits (if pop. }<2,500 \text { ) } \\
8.3 \text { percent of deposits (if pop }>2,500 \text { ) } \\
5 \text { percent of demand deposits and } 3.3 \text { percent of time } \\
\text { deposits (if pop. }<50,000 \text { ) } \\
8.3 \text { percent of demand deposits and } 3.3 \text { percent of time } \\
\text { deposits (if pop. }<50,000 \text { ) }\end{array}$ & $\begin{array}{c}\text { Tighter } \\
\text { Tighter } \\
\text { Easier }\end{array}$ & & \\
\hline Pennsylvania & 5 percent of deposits & Easier & 11 & 29 \\
\hline South Carolina & No law & Easier & 3 & 11 \\
\hline South Dakota & $\begin{array}{l}\text { None (Entire reserve may consist of deposits in other } \\
\text { banks) }\end{array}$ & Easier & 4 & 9 \\
\hline Tennessee & None reported & Easier & & \\
\hline Texas & 10 percent of demand deposits & Unclear & 5 & 12 \\
\hline Utah & $\begin{array}{l}\text { Reserve requirement, but banks determine the share to } \\
\text { be kept as cash }\end{array}$ & Easier & & \\
\hline Vermont & None reported & Easier & & \\
\hline Virginia & None reported & Easier & & \\
\hline Washington & 20 percent of demand deposits & Unclear & & \\
\hline West Virginia & 6 percent of demand deposits & Easier & 7 & 35 \\
\hline Wisconsin & $\begin{array}{l}\text { Reserve requirement, but banks determine the share to } \\
\text { be kept as cash }\end{array}$ & Easier & & \\
\hline Wyoming & None reported & Easier & & \\
\hline
\end{tabular}

Note: The symbol * indicates that information for the state was not listed in the data of the National Monetary Commission. While North Carolina is one of the states in our database, it did not have any banks meeting the sample requirements. The Report of the Comptroller of the Currency for 1895 indicates that the laws for these states were the same as for the National banks. 
Table 2

State bank summary statistics for 1906

\begin{tabular}{|c|c|c|c|c|}
\hline & Mean & Std. Dev. & Min. & Max. \\
\hline Reserves & 0.055 & 0.036 & 0.010 & 0.309 \\
\hline Ln(assets) & 13.247 & 1.202 & 9.281 & 17.153 \\
\hline (Capital + profits) /assets & 0.228 & 0.139 & 0.000 & 0.964 \\
\hline Profits/(capital + profits) & 0.296 & 0.230 & 0.000 & 1.000 \\
\hline Due to others/(deposits + due to others) & 0.047 & 0.100 & 0.000 & 0.713 \\
\hline Fraction of local assets in national banks & 0.480 & 0.233 & 0.078 & 0.968 \\
\hline Avg. fraction of cash/assets in national banks & 0.060 & 0.017 & 0.040 & 0.122 \\
\hline Easier state bank reserve requirements & 0.598 & 0.491 & 0.000 & 1.000 \\
\hline $\operatorname{Ln}$ (population) & 10.999 & 0.901 & 9.207 & 13.733 \\
\hline Fraction non-white & 0.081 & 0.152 & 0.000 & 0.777 \\
\hline Urban & 0.533 & 0.241 & 0.000 & 0.986 \\
\hline Reserve city & 0.138 & 0.345 & 0.000 & 1.000 \\
\hline $\operatorname{Ln}$ (number of manufacturing firms) & 5.696 & 1.044 & 3.020 & 8.264 \\
\hline $\operatorname{Ln}($ number of banks) & 1.875 & 0.480 & 1.386 & 2.944 \\
\hline Clearinghouse in city & 0.441 & 0.497 & 0.000 & 1.000 \\
\hline
\end{tabular}

Notes: Table provides summary statistics for the paper's main variables. See text for sources. 
Table 3

Determinants of state bank cash reserves (1905-1909)

\begin{tabular}{|c|c|c|}
\hline & (1) & (2) \\
\hline Ln(assets) & $\begin{array}{c}-0.006^{* * *} \\
{[0.001]}\end{array}$ & $\begin{array}{c}-0.005 * * * \\
{[0.001]}\end{array}$ \\
\hline$($ Capital + profits $) /$ assets & $\begin{array}{c}0.003 \\
{[0.006]}\end{array}$ & $\begin{array}{l}-0.000 \\
{[0.006]}\end{array}$ \\
\hline Profits/(capital + profits) & $\begin{array}{c}-0.002 \\
{[0.003]}\end{array}$ & $\begin{array}{l}-0.001 \\
{[0.003]}\end{array}$ \\
\hline Due to others/(deposits + due to others) & $\begin{array}{c}0.058 * * * \\
{[0.007]}\end{array}$ & $\begin{array}{c}0.053 * * * \\
{[0.007]}\end{array}$ \\
\hline $\begin{array}{l}\text { Fraction of local assets in } \\
\text { national banks }\end{array}$ & $\begin{array}{c}0.007 \\
{[0.015]}\end{array}$ & $\begin{array}{c}0.005 \\
{[0.016]}\end{array}$ \\
\hline $\begin{array}{l}\text { Avg. fraction of cash/assets in } \\
\text { national banks }\end{array}$ & $\begin{array}{c}0.117 \\
{[0.088]}\end{array}$ & $\begin{array}{c}0.106 \\
{[0.088]}\end{array}$ \\
\hline Easier state bank reserve requirements & $\begin{array}{l}-0.023 * * * \\
{[0.009]}\end{array}$ & $\begin{array}{c}-0.022 * * \\
{[0.009]}\end{array}$ \\
\hline $\begin{array}{l}\text { Fraction of assets in NB * avg. fraction cash/assets } \\
\text { in NB }\end{array}$ & $\begin{array}{c}0.212 \\
{[0.236]}\end{array}$ & $\begin{array}{c}0.193 \\
{[0.250]}\end{array}$ \\
\hline $\begin{array}{l}\text { Fraction of assets in NB * easier state } \\
\text { reserve requirements }\end{array}$ & $\begin{array}{l}0.037^{*} \\
{[0.020]}\end{array}$ & $\begin{array}{l}0.035^{*} \\
{[0.020]}\end{array}$ \\
\hline $\begin{array}{l}\text { Avg. fraction cash/assets } * \text { easier state } \\
\text { reserve requirements }\end{array}$ & $\begin{array}{c}0.423^{* * *} \\
{[0.145]}\end{array}$ & $\begin{array}{c}0.402 * * * \\
{[0.141]}\end{array}$ \\
\hline $\begin{array}{l}\text { Fraction of assets in } \mathrm{NB} * \text { avg. fraction cash/assets } \\
\text { in NB * easier state reserve requirements }\end{array}$ & $\begin{array}{c}-0.912 * * * \\
{[0.337]}\end{array}$ & $\begin{array}{c}-0.855 * * \\
{[0.334]}\end{array}$ \\
\hline Ln(population) & & $\begin{array}{c}0.005^{* *} \\
{[0.002]}\end{array}$ \\
\hline Fraction non-white & & $\begin{array}{c}0.001 \\
{[0.005]}\end{array}$ \\
\hline Urban & & $\begin{array}{c}0.013^{* * *} \\
{[0.004]}\end{array}$ \\
\hline Reserve city & & $\begin{array}{c}0.001 \\
{[0.003]}\end{array}$ \\
\hline $\operatorname{Ln}$ (number of manufacturing firms) & & $\begin{array}{c}-0.008 * * * \\
{[0.002]}\end{array}$ \\
\hline $\operatorname{Ln}($ number of banks) & & $\begin{array}{c}-0.006 * * * \\
{[0.002]}\end{array}$ \\
\hline Clearinghouse in city & & $\begin{array}{c}0.009^{* * *} \\
{[0.001]}\end{array}$ \\
\hline Year fixed effects & Yes & Yes \\
\hline Observations & 3418 & 3418 \\
\hline R-squared & 0.125 & 0.141 \\
\hline
\end{tabular}

Note: The table provides the results of an ordinary least squares regression where the dependent variable is the ratio of cash to assets at a bank. The sample includes banks in all towns with at least 4 banks but fewer than 20 banks that also had some national bank activity. The symbols $* * *, * *$, and * indicate statistical significance at the 1,5 , and 10 percent levels respectively. Standard errors in brackets. 
Table 4

Determinants of state bank cash reserves (1905-1909) — with year interaction

$\operatorname{Ln}($ assets)

$($ Capital + profits $) /$ assets

Profits/(capital + profits)

Due to others/(deposits + due to others $)$

Fraction of local assets in national banks

Avg. fraction of cash/assets in national banks

Easier state bank reserve requirements

Fraction of assets in $\mathrm{NB} *$ avg. fraction cash/assets in NB

Fraction of assets in NB * easier state reserve requirements

Avg. fraction cash/assets * easier state reserve requirements

Fraction of assets in $\mathrm{NB} *$ avg. fraction cash/assets in $\mathrm{NB} *$ easier state reserve requirements

Triple interaction $* \mathrm{yr}==1906$

Triple interaction $* \mathrm{yr}==1907$

Triple interaction $* \mathrm{yr}==1908$

Triple interaction $* \mathrm{yr}==1909$

Year fixed effects

County-lLevel Controls

Observations

R-squared
(1)

\begin{tabular}{|c|c|}
\hline $\begin{array}{c}-0.006^{* * *} \\
{[0.001]}\end{array}$ & $\begin{array}{c}-0.005 * * * \\
{[0.001]}\end{array}$ \\
\hline $\begin{array}{c}0.003 \\
{[0.006]}\end{array}$ & $\begin{array}{c}-0.000 \\
{[0.006]}\end{array}$ \\
\hline $\begin{array}{c}-0.002 \\
{[0.003]}\end{array}$ & $\begin{array}{c}-0.001 \\
{[0.003]}\end{array}$ \\
\hline $\begin{array}{c}0.057 * * * \\
{[0.007]}\end{array}$ & $\begin{array}{c}0.053 * * * \\
{[0.007]}\end{array}$ \\
\hline $\begin{array}{c}0.009 \\
{[0.015]}\end{array}$ & $\begin{array}{c}0.006 \\
{[0.016]}\end{array}$ \\
\hline $\begin{array}{c}0.125 \\
{[0.089]}\end{array}$ & $\begin{array}{c}0.116 \\
{[0.089]}\end{array}$ \\
\hline $\begin{array}{c}-0.023 * * * \\
{[0.009]}\end{array}$ & $\begin{array}{c}-0.022 * * \\
{[0.009]}\end{array}$ \\
\hline $\begin{array}{c}0.201 \\
{[0.237]}\end{array}$ & $\begin{array}{c}0.181 \\
{[0.250]}\end{array}$ \\
\hline $\begin{array}{c}0.037 * \\
{[0.020]}\end{array}$ & $\begin{array}{c}0.034^{*} \\
{[0.020]}\end{array}$ \\
\hline $\begin{array}{c}0.428 * * * \\
{[0.145]}\end{array}$ & $\begin{array}{c}0.403 * * * \\
{[0.141]}\end{array}$ \\
\hline $\begin{array}{c}-1.089 * * * \\
{[0.344]}\end{array}$ & $\begin{array}{c}-1.009 * * * \\
{[0.341]}\end{array}$ \\
\hline $\begin{array}{c}0.083 \\
{[0.121]}\end{array}$ & $\begin{array}{c}0.056 \\
{[0.119]}\end{array}$ \\
\hline $\begin{array}{c}0.196 \\
{[0.134]}\end{array}$ & $\begin{array}{c}0.185 \\
{[0.132]}\end{array}$ \\
\hline $\begin{array}{c}0.260 * * \\
{[0.105]}\end{array}$ & $\begin{array}{c}0.242 * * \\
{[0.104]}\end{array}$ \\
\hline $\begin{array}{c}0.183 * \\
{[0.104]}\end{array}$ & $\begin{array}{c}0.179 * \\
{[0.104]}\end{array}$ \\
\hline Yes & Yes \\
\hline No & Yes \\
\hline 3418 & 3418 \\
\hline 0.127 & 0.143 \\
\hline
\end{tabular}

Note: The table provides the results of an ordinary least squares regression where the dependent variable is the ratio of cash to assets at a bank. The sample includes banks in all towns with at least 4 but fewer than 20 banks that also had some national bank activity. "County-Level Controls" include: logarithm of population, the share of the population defined living in a location of more than 2,500 people (i.e., an urban location), the share of population that was non-white, the logarithm of manufacturing firms. The symbols ***, **, and * indicate statistical significance at the 1, 5, and 10 percent levels respectively. Standard errors in brackets. 
Table 5

Determinants of state bank closure (1906-1908)

\begin{tabular}{|c|c|c|c|c|}
\hline & $\begin{array}{l}\text { All state } \\
\text { banks } \\
(1)\end{array}$ & $\begin{array}{l}\text { State banks in } \\
\text { cities with at } \\
\text { least one } \\
\text { other bank } \\
\text { (2) }\end{array}$ & $\begin{array}{l}\text { State banks in } \\
\text { cities with at } \\
\text { least one } \\
\text { national bank } \\
\text { (3) }\end{array}$ & $\begin{array}{c}\text { Banks in } \\
\text { cities with } \\
\text { between } 4 \text { and } \\
19 \text { banks } \\
(4)\end{array}$ \\
\hline Cash to assets & $\begin{array}{l}-0.057 \\
{[0.079]}\end{array}$ & $\begin{array}{l}-0.199 * \\
{[0.115]}\end{array}$ & $\begin{array}{l}-0.273^{*} \\
{[0.164]}\end{array}$ & $\begin{array}{c}-0.012 \\
{[0.358]}\end{array}$ \\
\hline Ln(assets) & $\begin{array}{c}-0.017 * * * \\
{[0.004]}\end{array}$ & $\begin{array}{c}-0.027 * * * \\
{[0.005]}\end{array}$ & $\begin{array}{c}-0.032 * * * \\
{[0.006]}\end{array}$ & $\begin{array}{l}-0.030 * \\
{[0.017]}\end{array}$ \\
\hline$($ Capital + profits $) /$ assets & $\begin{array}{l}0.060 * * \\
{[0.026]}\end{array}$ & $\begin{array}{l}0.066^{*} \\
{[0.036]}\end{array}$ & $\begin{array}{c}0.042 \\
{[0.047]}\end{array}$ & $\begin{array}{c}0.103 \\
{[0.100]}\end{array}$ \\
\hline Profits/(capital + profits $)$ & $\begin{array}{l}-0.014 \\
{[0.018]}\end{array}$ & $\begin{array}{l}-0.017 \\
{[0.025]}\end{array}$ & $\begin{array}{c}0.008 \\
{[0.031]}\end{array}$ & $\begin{array}{c}0.099 \\
{[0.073]}\end{array}$ \\
\hline $\begin{array}{l}\text { Due to others/(deposits }+ \text { due to } \\
\text { other banks) }\end{array}$ & $\begin{array}{l}0.086 * * \\
{[0.040]}\end{array}$ & $\begin{array}{l}0.115^{* *} \\
{[0.052]}\end{array}$ & $\begin{array}{c}0.168 * * * \\
{[0.061]}\end{array}$ & $\begin{array}{l}-0.013 \\
{[0.138]}\end{array}$ \\
\hline Ln(population) & $\begin{array}{l}-0.002 \\
{[0.010]}\end{array}$ & $\begin{array}{l}-0.018 \\
{[0.014]}\end{array}$ & $\begin{array}{l}-0.020 \\
{[0.022]}\end{array}$ & $\begin{array}{l}-0.072 \\
{[0.049]}\end{array}$ \\
\hline Fraction non-white & $\begin{array}{c}0.014 \\
{[0.020]}\end{array}$ & $\begin{array}{c}0.014 \\
{[0.030]}\end{array}$ & $\begin{array}{c}0.037 \\
{[0.042]}\end{array}$ & $\begin{array}{c}0.081 \\
{[0.098]}\end{array}$ \\
\hline Urban & $\begin{array}{c}0.053 * * \\
{[0.022]}\end{array}$ & $\begin{array}{c}0.060 * \\
{[0.031]}\end{array}$ & $\begin{array}{c}0.095 * * \\
{[0.040]}\end{array}$ & $\begin{array}{c}0.015 \\
{[0.104]}\end{array}$ \\
\hline Reserve city & $\begin{array}{c}-0.007 \\
{[0.014]}\end{array}$ & $\begin{array}{c}-0.009 \\
{[0.017]}\end{array}$ & $\begin{array}{c}-0.009 \\
{[0.019]}\end{array}$ & $\begin{array}{c}0.021 \\
{[0.051]}\end{array}$ \\
\hline Ln(number of manufacturing firms) & $\begin{array}{c}-0.017 * * \\
{[0.008]}\end{array}$ & $\begin{array}{c}-0.010 \\
{[0.011]}\end{array}$ & $\begin{array}{c}-0.010 \\
{[0.018]}\end{array}$ & $\begin{array}{c}0.051 \\
{[0.046]}\end{array}$ \\
\hline Ln(number of banks) & $\begin{array}{c}0.042^{* * *} * \\
{[0.005]}\end{array}$ & $\begin{array}{c}0.055^{* * *} * \\
{[0.008]}\end{array}$ & $\begin{array}{c}0.052 * * * \\
{[0.011]}\end{array}$ & $\begin{array}{c}0.066 \\
{[0.047]}\end{array}$ \\
\hline Easier state bank reserve requirements & $\begin{array}{c}-0.020 * * * \\
{[0.006]}\end{array}$ & $\begin{array}{c}-0.023 * * \\
{[0.009]}\end{array}$ & $\begin{array}{c}-0.019 \\
{[0.012]}\end{array}$ & $\begin{array}{c}-0.049 \\
{[0.030]}\end{array}$ \\
\hline Clearinghouse in city & $\begin{array}{c}0.015 \\
{[0.014]}\end{array}$ & $\begin{array}{c}0.025 \\
{[0.020]}\end{array}$ & $\begin{array}{c}0.019 \\
{[0.022]}\end{array}$ & $\begin{array}{c}-0.035 \\
{[0.035]}\end{array}$ \\
\hline $\begin{array}{l}\text { Observations } \\
\text { Pseudo R-squared }\end{array}$ & $\begin{array}{l}7240 \\
0.043\end{array}$ & $\begin{array}{l}4226 \\
0.049\end{array}$ & $\begin{array}{l}2391 \\
0.061\end{array}$ & $\begin{array}{c}618 \\
0.027\end{array}$ \\
\hline
\end{tabular}

Note: The table provides the marginal effects evaluated at the mean from a logit regression. The dependent variable is whether the bank was observed in 1908. The sample consists of all those banks present in 1906 that meet the condition in the column title. We drop New York trust companies from the sample because they were at the heart of the panic. The symbols $* * *, * *$, and * indicate statistical significance at the 1,5 , and 10 percent levels respectively. Standard errors in brackets. 


\section{ONLINE APPENDIX}

\section{Section 1. Importance of the control variables and location characteristics}

As regional and geographic factors may have played a role in shaping banks' preferences about cash holdings, it is useful to understand how the inclusion or exclusion of the associated control variables affects our findings. Table 3 in the paper show how the results differ (or, in our case, are not notably affected) by the inclusion or exclusion of all city and country controls. A further illustration of the impact of the inclusion or exclusion of various controls, is provided in Table A1. In column 2 of this Table, we report results only include the city level controls (plus county population). In column 3, we report results only using county and state level controls. There is not much variation in the variable of interest, the triple-interaction term, across the different specifications.

In addition, in Table A2 we report the correlation of all the location characteristics with the interaction of the share of a city's bank assets in national banks and the average share of cash to assets at the national banks (two parts of our triple interaction term). We do not find any evidence of especially high correlations. The highest is for reserve cities at 0.39 ; this particular correlation likely reflects the higher cash requirements for national banks in these cities.

Section 2. Robustness regarding cutoffs with respect to the number of banks in the city

The selection of cutoff points for the sample - focusing on cities with 4-19 banks - is based on a variety of factors. For the bottom cutoff, existing literature such as James, Weiman, and McAndrews (2013) has highlighted that free riding was occurring in larger cities because of the existence of interbank markets for cash. Moreover, one might be concerned about using fractional measures for national banks' size and cash holdings in places where they were the only 
other bank because much of the variation would just be based on the singular presence of a national bank rather than variation in national bank behavior. For the top cutoff, the literature has highlighted that banks in central reserve cities and important regional reserve cities, may have been held to different standards if they wanted to compete for interbank deposits. Note that the restriction to less than 20 banks typically only drops out 14 cities and every one of them are either a central reserve city or a reserve city which were subject to differential national bank reserve requirements. Moreover, clearinghouses in these financial centers set higher rules for local banks; for instance, the New York City Clearinghouse required all members, both state and national banks, to meet the legal reserve requirements of the national banks.

Nevertheless it is helpful to show how the baseline model is affected if those cutoffs are altered. We estimate our baseline model for a variety of samples that include cities with a range of numbers of banks to illustrate how including smaller or larger cities impacts the results. Table A3 below shows the size and significance of the triple interaction term for these other cutoffs. The table shows that the coefficient on the triple interaction is negative and significant for any lower cutoff value and only becomes statistically insignificant when a much higher upper cutoff value is used. 
Table A1

Determinants of state bank cash reserves (1905-1909)

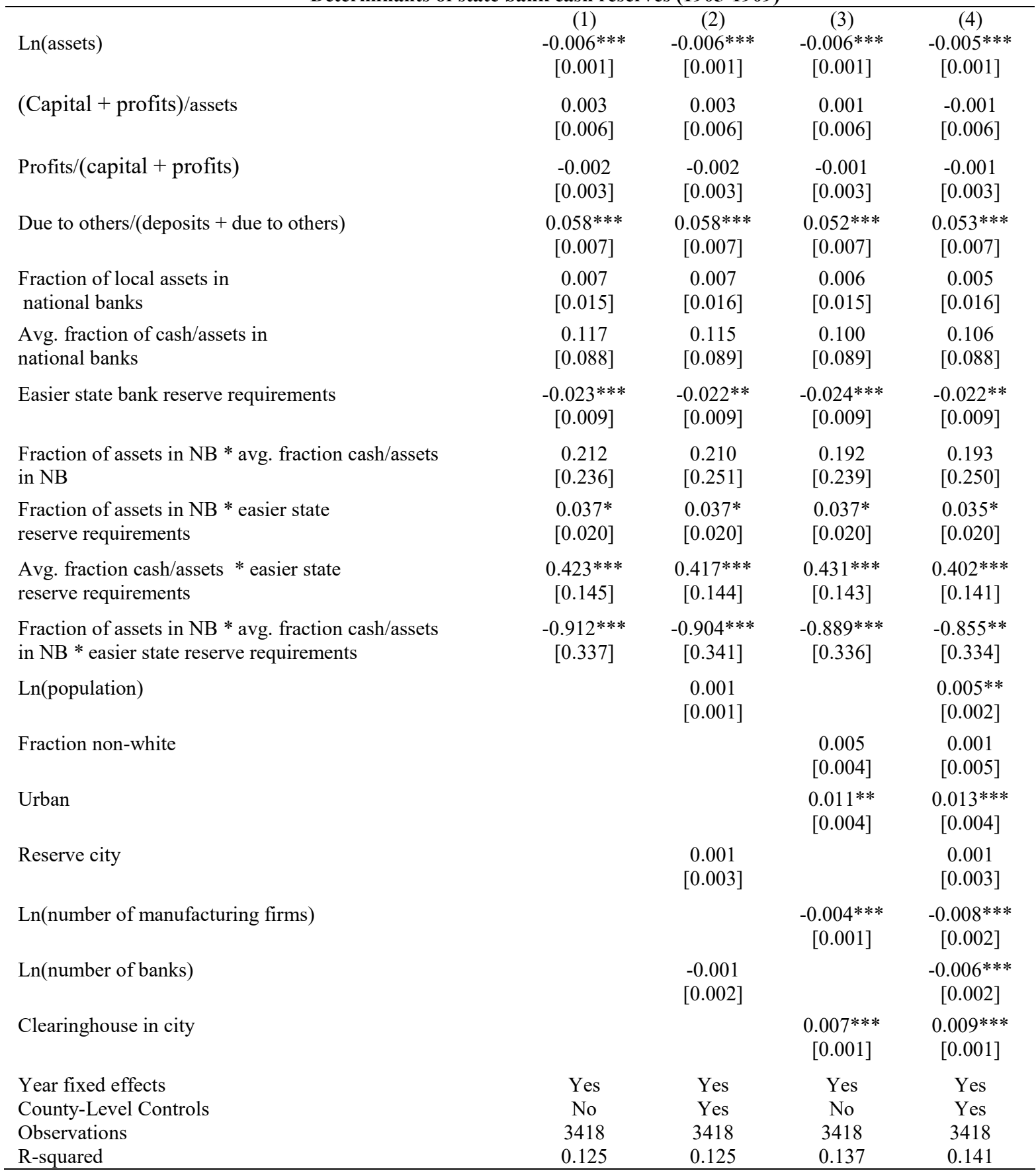

Note. The table provides the results of an ordinary least squares regression where the dependent variable is the ratio of cash to assets at a bank. Limited to banks used in the baseline analysis. The symbols ***, ${ }^{* *}$, and * indicate statistical significance at the 1,5, and 10 percent levels respectively. Standard errors in brackets. 
Table A2

Correlation of location and (national bank cash holdings * national bank asset share)

\begin{tabular}{|l|c|}
\hline & Correlation coefficient \\
\hline Fn(population) & -0.0045 \\
\hline Urban & 0.0377 \\
\hline Reserve city & 0.0688 \\
\hline Ln(number of manufacturing firms) & 0.4083 \\
\hline Ln(number of banks) & -0.077 \\
\hline Clearinghouse in city & 0.0493 \\
\hline
\end{tabular}

Note. Limited to locations in our baseline sample 


\section{Table A3}

Size, standard error, and statistical significance of the coefficient on the triple interaction term for different numbers of banks in the city used as cutoffs for inclusion in the sample

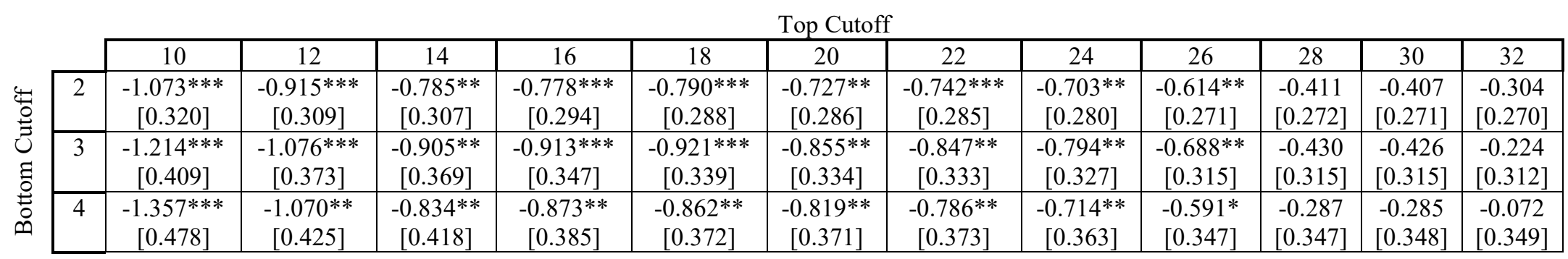

Notes: The table provides the estimates coefficient for the triple interaction in equation (1) using different upper and lower cutoffs. 